\title{
TANTALUM OXIDE DIELECTRICS PROCESSED WITH SPARK-PLASMA SINTERING
}

\author{
TANTAL OKSIDNI DIELEKTRIK, IZDELAN S TEHNIKO \\ SINTRANJA V PULZIRAJOČEM OBLOKU PLAZME
}

\author{
Pavel Ctibor ${ }^{1,2}$, Josef Sedláček ${ }^{2}$, Tomáš Hudec ${ }^{2}$ \\ ${ }^{1}$ Institute of Plasma Physics, ASCR, Za Slovankou 3, 18200 Prague 8, Czech Republic \\ ${ }^{2}$ Faculty of Electrical Engineering, Czech Technical University, Technicka 2, 16627 Prague 6, Czech Republic
}

Prejem rokopisa - received: 2019-04-04; sprejem za objavo - accepted for publication: 2019-10-08

doi:10.17222/mit. 2019.074

\begin{abstract}
Tantalum pentoxide $\left(\mathrm{Ta}_{2} \mathrm{O}_{5}\right)$ was sintered with spark-plasma sintering (SPS) using a commercial powder with micometric particles composed of nanometric crystallites. The influence of the SPS process and subsequent annealing on the microstructure, phase composition and dielectric properties was studied. After the sintering, the product was oxygen deficient because of the low pressure in the sintering chamber. Evacuation was necessary for the process because of the carbon pistons and carbon die used for the powder compaction. After the subsequent annealing in air, the white color of $\mathrm{Ta}_{2} \mathrm{O}_{5}$ was restored, being a proper indication of a re-oxidation. Dielectric properties were studied in a broad range of frequencies and temperatures. As-sintered and also annealed samples exhibited a high relative permittivity in a range of 61-68, a loss factor of about 0.001 and a resistivity in the order of $10^{11} \Omega \mathrm{m}$.

Keywords: tantalum oxide, dielectrics, spark-plasma sintering
\end{abstract}

Tantalov pentoksid $\mathrm{Ta}_{2} \mathrm{O}_{5}$ so avtorji članka zgoščevali s postopkom sintranja v pulzirajočem obloku plazme (SPS). Pri tem so uporabili komercialni prah mikrometrske velikosti delcev, sestavljenih iz nanometričnih kristalčkov. Avtorji so študirali vpliv SPS-procesa in nadaljnjega žarjenja na mikrostrukturo, fazno sestavo in dielektrične lastnosti. Po sintranju so imeli sintrani vzorci zmanjšano vsebnost kisika zaradi nizkega tlaka v komori za sintranje. Evakuiranje je bilo potrebno, saj so bili za zgoščevanje uporabljeni grafitni pestiči oz. trni in orodje. Po naknadnem žarjenju na zraku se je povrnila $\mathrm{Ta}_{2} \mathrm{O}_{5}$ bela barva, kar je bil znak, da je prišlo do ponovne oksidacije oz. reoksidacije. Avtorji so dielektrične lastnosti vzorcev študirali $\mathrm{v}$ širokem razponu frekvenc in temperatur. Sintrani in prav tako žarjeni vzorci so imeli visoko relativno permitivnost, med 61 in 68 , faktor izgub okoli 0,001 in upornost reda velikosti $10^{11} \Omega \mathrm{m}$.

Ključne besede: tantalov oksid, dielektrik, sintranje v pulzirajočem obloku plazme

\section{INTRODUCTION}

Tantalum pentoxide $\left(\mathrm{Ta}_{2} \mathrm{O}_{5}\right)$ has a density of $8.2 \mathrm{~g} / \mathrm{cm}^{3}$ and a melting point of $1872{ }^{\circ} \mathrm{C}$. Two polymorphs are known, a low-temperature orthorhombic form known as $\mathrm{L}-$ or $\beta-\mathrm{Ta}_{2} \mathrm{O}_{5}$, and a high-temperature form known as $\mathrm{H}$ or $\alpha-\mathrm{Ta}_{2} \mathrm{O}_{5}$. The transition between these two forms is slow and reversible, taking place between $1000-1360{ }^{\circ} \mathrm{C}$, with a mixture of structures existing at intermediate temperatures.

Tantalum pentoxide is extensively studied for its attractive properties in dielectric films, anti-reflection coatings and resistive switching memory. Although various crystalline structures of tantalum pentoxide have been reported on, its structural, electronic and optical properties are still a subject of research. It is an electrical insulator with a band gap of approximately $4.5 \mathrm{eV}$. Due to its high dielectric constant, chemical stability, high breakdown strength and low leakage current, tantalum pentoxide is a strong candidate for various applications among the high dielectric constant materials. The electrical performance of $\mathrm{Ta}_{2} \mathrm{O}_{5}$ films is greatly influenced by

*Corresponding author's e-mail:

ctibor@ipp.cas.cz (Pavel Ctibor) oxide charges in the bulk material as well as by the interface state charges. Oxygen vacancies are the principal source of charges and bulk defects in $\mathrm{Ta}_{2} \mathrm{O}_{5}$, and they can be efficiently reduced in an oxidizing environment during a deposition or during thermal post-treatments. Therefore, the dielectric characteristics of $\mathrm{Ta}_{2} \mathrm{O}_{5}$ films are improved after oxygen annealing. The effect of oxygen annealing also depends on the annealing temperature, and annealing leads to a very pronounced decrease of the leakage current of $\mathrm{Ta}_{2} \mathrm{O}_{5}$ at room temperature. Its dielectric constant is typically about 25 although values of over 50 have been reported as well. In general, tantalum pentoxide is considered to be a highly polarizable dielectric material. ${ }^{1-6}$

The dielectric constant and a loss factor of 2- $\mu \mathrm{m}$ films were reported as 21 and 0.003 , respectively, at $1 \mathrm{kHz}$ and room temperature. ${ }^{7}$ Elsewhere a dielectric constant of 22-30 was reported ${ }^{8}$ and so was a breakdown strength of $30-35 \mathrm{kV} \cdot \mathrm{mm}^{-1}$. This thin film was produced due to the oxidation of sputtered or electron-beamdeposited metallic Ta films. The oxygen in the working gas mixture contributed to reducing the density of oxygen vacancies during the RF magnetron sputtering deposition process. For the films deposited in working 
gas mixtures with different $\mathrm{O}_{2} / \mathrm{Ar}$ ratios and subsequently annealed at $700{ }^{\circ} \mathrm{C}$, the effective dielectric constant was increased from 14.7 for pure Ar to 18.4 for pure $\mathrm{O}_{2} \cdot{ }^{9}$

Spark-plasma sintering enables a very rapid fabrication of bulk ceramic materials. It is an emerging consolidation technique, which combines pulsed electric currents and uniaxial pressure-induced compaction. Heating rates, applied pressures and pulsed current patterns are the main factors responsible for the enhancement of densification kinetics and conservation of the submicron-scale structure of the materials. Concerning the application of spark-plasma sintering (SPS) technology for $\mathrm{Ta}_{2} \mathrm{O}_{5}$, the available literature is almost non-existent. Tantalum oxide was only applied as a dopant into an SPS-processed tin oxide $\left(\mathrm{SnO}_{2}\right) .{ }^{10} \mathrm{In}$ another case, tantalum carbide was SPS-sintered and the tantalum oxide presence in the final product was reported $^{11}$. The goal of our study is to observe the influence of sintering on the dielectric properties of pure $\mathrm{Ta}_{2} \mathrm{O}_{5}$ sintered from a commercial micrometric powder.

\section{EXPERIMENTAL PART}

Powder 73R-0802 (Inframat, CT, USA), as-received, i.e. non-annealed, with a composition of $\mathrm{Ta}_{2} \mathrm{O}_{5}(99 \%$
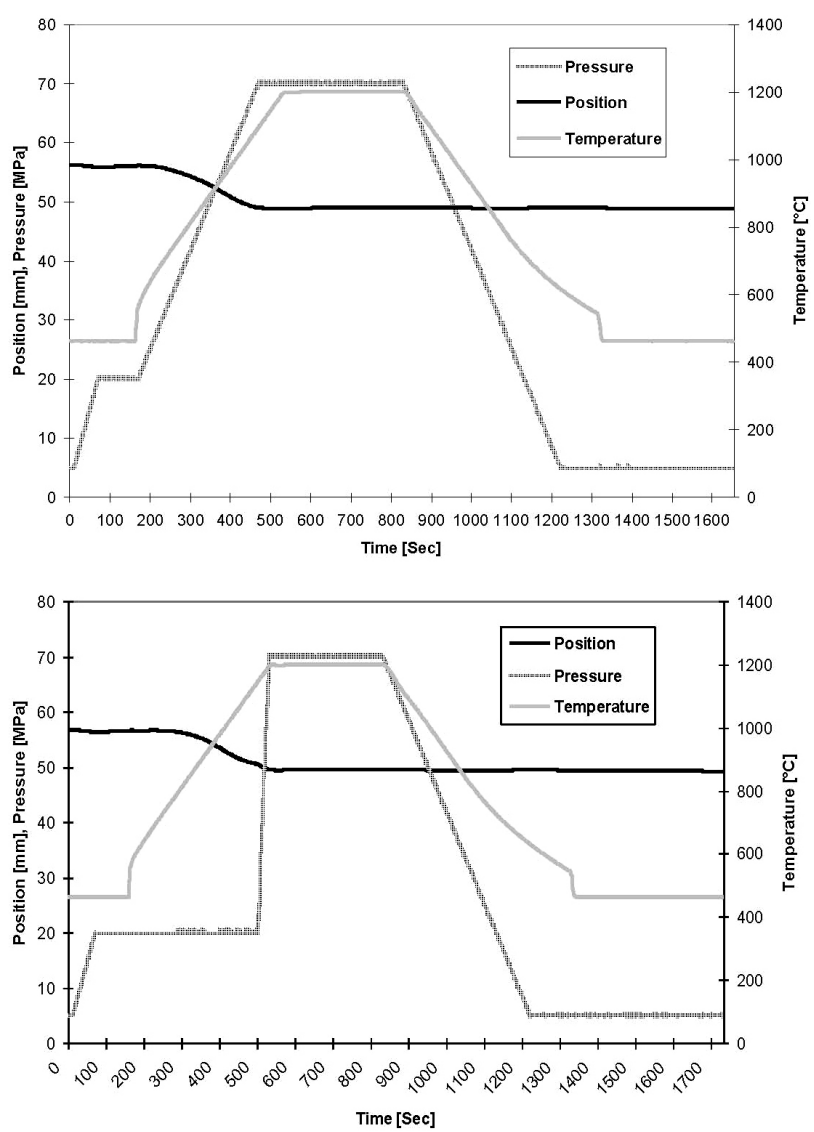

Figure 1: a) RAMP-sample sintering regime, b) STEP-sample sintering regime purity) and the average size of $3 \mu \mathrm{m}$ (producer data) was sintered at $1200{ }^{\circ} \mathrm{C}$, with a $70-\mathrm{MPa}$ applied pressure and 5 -min dwell time at the maximum temperature. The difference between two applied regimes of sintering was in the pressure ramp. In the first experiment, the pressure started to increase monotonously in the same moment as the temperature (the sample labeled as R (ramp), Figure 1a). In the second experiment, the pressure increased within a few seconds from $20 \mathrm{MPa}$ to $70 \mathrm{MPa}$ in the moment of reaching $1200{ }^{\circ} \mathrm{C}$ (the sample labeled as $\mathrm{S}$ (step), Figure 1b). The curve labeled "position" indicates volume change of the sample space due to applied pressure. It is very similar for both sample experiments.

The annealing, applied onto the "ramp" coating as a thermal post-processing, had a dwell time of $10 \mathrm{~h}$ at $1100{ }^{\circ} \mathrm{C}$ in air atmosphere. The color of the sample changed markedly, Figure 2. Changing back to white (which is the color of the starting powder) is due to the reoxidation of the oxide ceramic. ${ }^{12}$

The powder X-ray diffraction (PXRD) measurements were carried out on a vertical $\theta-\theta$ D8 Discover difractometer (Bruker AXS, Germany) using $\mathrm{Cu}-K \alpha$ radiation. The diffracted beam was detected by a LynxEye 1D detector. The angular range was from $20^{\circ}$ to $95^{\circ} 2 \theta$. Quantitative Rietveld refinement was performed in the TOPAS V5 software using the fundamental-parameter approach for the evaluation of lattice parameters, average sizes of coherently scattering domains and microstrains.

The surface of specimens was made smooth by grinding to eliminate the surface roughness and possible superficial contamination from the carbon foils used during SPS.

Scanning electron microscopy (SEM) was done using a Phenom-Pro microscope (Thermo Fisher Sci., Eindhoven, The Netherlands) equipped with a $\mathrm{CeB}_{6}$ thermionic cathode and working in the backscattered-electron (BSE) mode. The images were collected at a $10-\mathrm{kV}$ electron-beam tension.

Layers of aluminum as thin-film electrodes were sputtered under reduced pressure on both sides of each sample. A three-electrode measurement fixture was used to measure the dielectric parameters of the SPS samples.

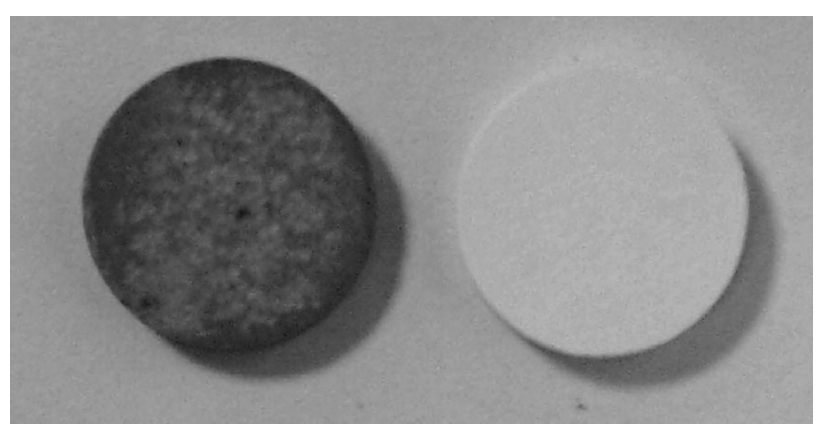

Figure 2: As-sintered sample (left) and annealed sample, both photographed before the final elimination of the roughness for the dielectric measurements 
An electric field was applied parallel to the pressure direction (i.e., perpendicular to the substrate surface).

The capacitance at room temperature was recorded in a frequency range from $180 \mathrm{~Hz}$ to $1 \mathrm{MHz}$ using a programmable impedance analyzer, model 4284A (Agilent, USA). The applied voltage was $1 \mathrm{~V}$ AC. Relative permittivity $\varepsilon_{\mathrm{r}}$ was calculated from measured capacities $C_{\mathrm{P}}$ and specimen dimensions. The same arrangement and equipment were used for the loss tangent measurement, made at the same frequencies as the capacitance measurement.

Electric resistance was measured with a special resistivity adapter - Keithley, model 6105. A DC electric field was applied from a regulated high-voltage source and the values were read by a multi-purpose electrometer (617C, Keithley Instruments, USA). The magnitude of the applied voltage was $100 \pm 0.05 \mathrm{~V}$. The volume resistivity was calculated from the measured resistance and specimen dimensions.

The capacitance, loses as well as resistance were also measured at elevated temperatures of up to $150{ }^{\circ} \mathrm{C}$. Switchboard model 7490 A (Agilent, USA) and thermometric chamber model 3140 Isocal Venus (a temperature range from $-40{ }^{\circ} \mathrm{C}$ to $+150{ }^{\circ} \mathrm{C}$ ) were applied.

The Vickers microhardness of the same samples as for the dielectric measurement was measured on polished surfaces with an optical microscope equipped with a Hanemann head and Vickers indenter using a 1-N load. The mean value of the microhardness was calculated as the average of 20 indentations.

\section{RESULTS AND DISCUSSION}

\subsection{Phase composition}

Orthorhombic $\mathrm{Ta}_{2} \mathrm{O}_{5}$ (ICDD \# 00-025-0922) was the only detected phase in the starting powder (Figure 3a), as found also for the thin film. ${ }^{9}$ The crystallite size of the starting powder was $63 \mathrm{~nm}$. The $\mathrm{Ta}_{2} \mathrm{O}_{5}$ powder was annealed at $1250{ }^{\circ} \mathrm{C}$ for $10 \mathrm{~h}$ in air to subject it to a thermal load without sintering it. Its crystallite size was $240 \mathrm{~nm}$ after this treatment. The annealed powder (Figure 3a) contained orthorhombic $\mathrm{Ta}_{2} \mathrm{O}_{5}$ (ICDD \# 00-025-0922) and also $3.3 \%$ of hydrated phase $\mathrm{Ta}_{2} \mathrm{O}_{5}\left(\mathrm{H}_{2} \mathrm{O}\right)_{0.667}$ (ICDD \# 01-073-4210). Much narrower peaks of the annealed powder suggest that defects were annealed out. SPS-fired sample S (Figure 3b) contained only the $\mathrm{Ta}_{2} \mathrm{O}_{5}$ phase with a crystallite size of $59 \mathrm{~nm}$. Sample R (Figure 3c) exhibited a crystallite size of $85 \mathrm{~nm}$, the preferred orientation (texture) was the 001 direction and the lattice parameters were closer to the starting powder than to the annealed powder. The preferred grain-growth orientation was, due to the pressure, applied during the whole heating process. Annealed sample R (Figure 3d) contained besides orthorhombic $\mathrm{Ta}_{2} \mathrm{O}_{5}$ (ICDD \# 00-025-0922) also $3.84 \%$ of hydrated phase $\mathrm{Ta}_{2} \mathrm{O}_{5}\left(\mathrm{H}_{2} \mathrm{O}\right)_{0.667}$ (ICDD \# 01-0734210). The crystallite size of the major phase was
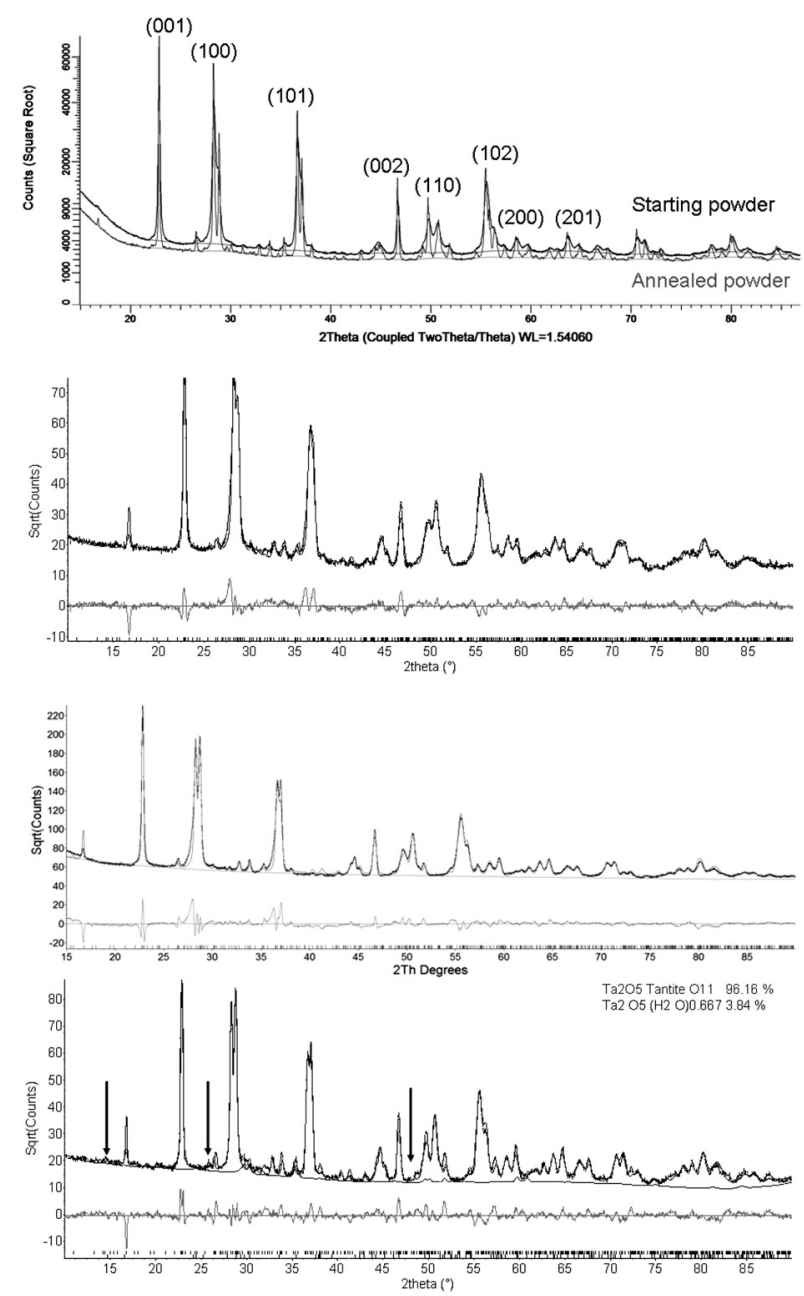

Figure 3: a) XRD patterns of the starting powder and annealed powder, b) XRD pattern of sample $S$ (the "RWP curve" indicating the agreement of the peaks with the standardized charts is below the pattern), c) XRD pattern of sample R, d) XRD pattern of the annealed sample $\mathrm{R}$. The most intense peaks of the water-containing phase are indicated by the arrows. (The "RWP curve" indicating the agreement of the peaks with the standardized charts are below the patterns.)

$108 \mathrm{~nm}$. $\mathrm{Ta}_{2} \mathrm{O}_{5}$ seems to be very sensitive to ambient moisture during cooling when it is in the form of powder or in the form of sintered bulk. A fast SPS process is an effective way of avoiding this hydration. Lattice parameters of our samples are in good agreement with the comprehensive results provided in ${ }^{13-15}$.

The way of possible hydration is indicated below (the inverse run of reaction 2): During the production of $\mathrm{Ta}_{2} \mathrm{O}_{5}$, the tantalum hydrogen fluoride solution is neutralized with aqueous ammonia to give hydrated tantalum oxide $\left(\mathrm{Ta}_{2} \mathrm{O}_{5}\left(\mathrm{H}_{2} \mathrm{O}\right)_{\mathrm{x}}\right)$, which is calcined to tantalum pentoxide $\left(\mathrm{Ta}_{2} \mathrm{O}_{5}\right)$ as described in these idealized Equations (1-2): ${ }^{16}$

$$
\begin{aligned}
& \mathrm{H}_{2}\left[\mathrm{TaF}_{7}\right]+5 \mathrm{H}_{2} \mathrm{O}+7 \mathrm{NH}_{3} \rightarrow \\
& \rightarrow 0.5 \mathrm{Ta}_{2} \mathrm{O}_{5}\left(\mathrm{H}_{2} \mathrm{O}\right)_{5}+7 \mathrm{NH}_{4} \mathrm{~F} \\
& \mathrm{Ta}_{2} \mathrm{O}_{5}\left(\mathrm{H}_{2} \mathrm{O}\right)_{5} \rightarrow \mathrm{Ta}_{2} \mathrm{O}_{5}+5 \mathrm{H}_{2} \mathrm{O}
\end{aligned}
$$



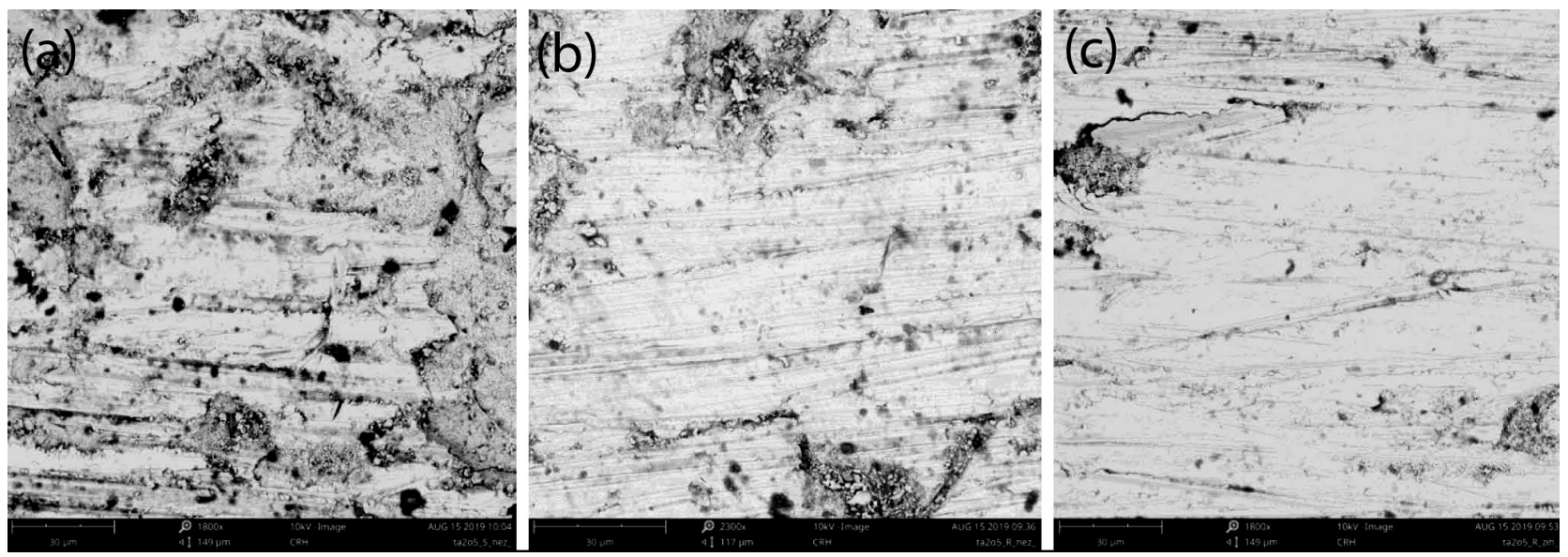

Figure 4: SEM-BSE micrographs, image width $135 \mu \mathrm{m}$ : a) as-sintered sample $\mathrm{S}$, b) as-sintered sample R, c) annealed sample R

\subsection{Microstructure}

Figure 4 presents SEM micrographs of the samples after the mechanical removal of residual carbon from superficial layers by grinding. That is why the images present a combination of a worn surface and deeper "craters" with a material not influenced by grinding. The concentration of surface defects including scratches and pores (black) was the highest for as-sintered sample S. Deeper craters on this sample contained relatively fine particles, crating not well-sintered islands with a large size and high concentration. In as-sintered sample R, the quantity and character of scratches are less dramatic. Also, the craters of not well-sintered powder material are less frequent. After the annealing, sample R obtained an even, much smoother surface. The crack, present in the upper part of the micrograph, indicates a more brittle behavior of this microstructure.

\subsection{Dielectric measurements at room temperature}

The results are displayed in Figures 5 to 7. The relative permittivity and loss factor were recorded for the

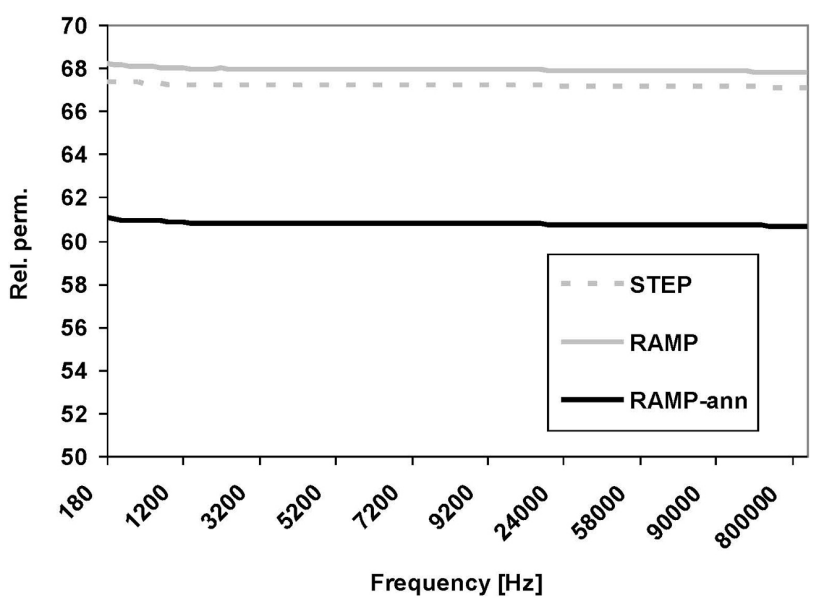

Figure 5: Frequency dependence of the relative permittivity of the samples before and after (marked with -ann) annealing frequency range of $180 \mathrm{~Hz}$ to $1 \mathrm{MHz}$. Figure $\mathbf{5}$ shows a very stable run of the relative permittivity (i.e., dielectric constant) over the whole frequency range. Concerning the samples, as-sintered sample $\mathrm{R}$ had the highest value of about 68 and as-sintered sample $S$ had just a slightly lower value about 67.5. The annealing slightly lowered the value for sample $\mathrm{R}$ down to 61 . The permittivity value of the $\mathrm{Ta}_{2} \mathrm{O}_{5}$ thin film was reported to be only $31 .{ }^{9}$

The run of the loss factor in the whole frequency range is displayed in Figure 6. All the samples exhibited a decreasing loss with the frequency. At frequencies above $5 \mathrm{kHz}$ the values were nearly constant, between 0.0005 and 0.001 . At lower frequencies the losses were higher, particularly for sample $\mathrm{R}$ (both as-sintered and annealed) reaching 0.0033 at $200 \mathrm{~Hz}$. However, the values at $1 \mathrm{MHz}$ for all the samples were: a permittivity $\left(\varepsilon_{\mathrm{r}}\right)$ of $61-68$ and a loss factor $(\operatorname{tg} \delta$ ) of about 0.0008 . This is a promising behavior for future applications because of the current lack of the available materials with $\varepsilon_{\mathrm{r}}$ in a range of $45-75 .{ }^{17}$ Especially the materials with a chemically simple composition such as $\mathrm{Ta}_{2} \mathrm{O}_{5}$ (without any additives) are rare in the mentioned permittivity range. As a higher dielectric loss for the $\mathrm{R}$

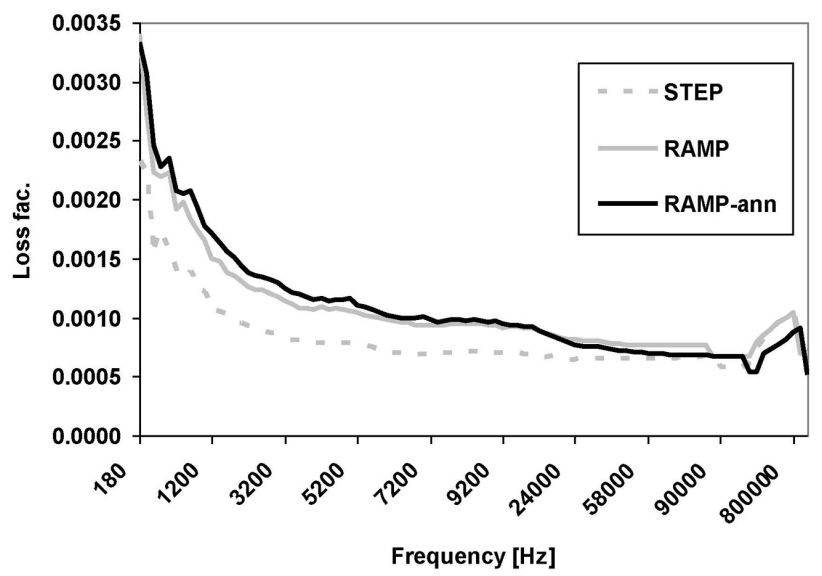

Figure 6: Frequency dependence of the loss factor of samples before and after (marked with -ann) annealing 


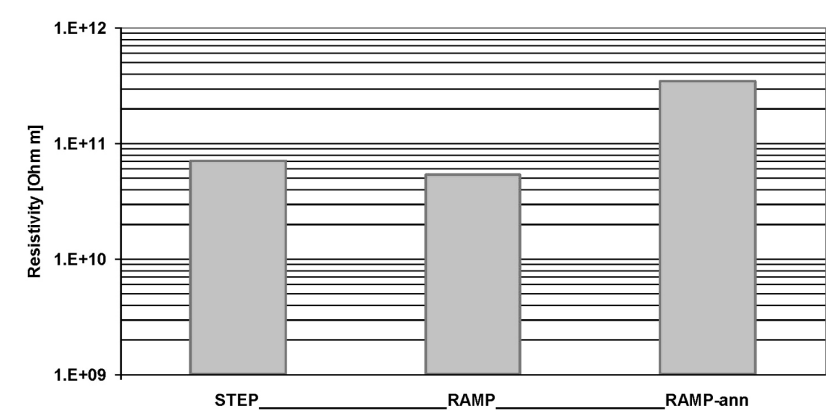

Figure 7: Comparison of the resistivity of all sample classes are marked (annealed labeled -ann)

sample in the as-sintered and annealed condition is observed at a low frequency, at least up to $1 \mathrm{kHz}$, the space charge may be the main mechanism responsible for the dielectric loss. Typically, thin films have a lower permittivity of 26-30 at a loss factor of about $0.06 .{ }^{18}$

The volume resistivity measured in the DC field is displayed in Figure 7. All the samples exhibited a rather high resistivities between $5 * 10^{10}$ and $4 * 10^{11} \Omega \mathrm{m}$. Annealed sample R exhibited a higher resistivity than the as-sintered one, thanks to the reoxidation of lattice defects, namely vacancies, responsible for the darker color of the as-sintered samples.

The SPS-produced bulk samples are better dielectrics than the reported $\mathrm{Ta}_{2} \mathrm{O}_{5}$ films ${ }^{7}$ because at $1 \mathrm{kHz}$ thin films had a relative permittivity of 21 and, simultaneously, a loss factor of 0.003 . At a higher frequency, the losses of the SPS-samples were even lower.

\subsection{Dielectric measurements at elevated temperatures}

The relative permittivity at elevated temperatures and $1 \mathrm{MHz}$ frequency is shown in Figure 8. Because of its combination with the room-temperature data $\left(20{ }^{\circ} \mathrm{C}\right)$ obtained with another measurement set-up, different from the rest of the values, the observed misalignment is an artifact and not the material property. As-sintered sample $\mathrm{S}$ has a lower value (about 50) compared to sample R (about 65). However, after the annealing, sample R exhibits a reduced permittivity (about 45 ).

The loss factor is displayed as well. As-sintered sample $S$ has a lower value (of about 0.002) compared to sample R (about 0.010). After the annealing, sample R exhibits lower losses (about 0.008). Moreover, sample $R$ has certain local maxima of the loss-factor curve - in the as-sintered state at $150{ }^{\circ} \mathrm{C}$ and in the annealed state at $65{ }^{\circ} \mathrm{C}$.

The results indicate that the as-sintered $\mathrm{R}$ sample exhibits a certain conduction that substitutes the true polarization. This is manifested by high losses at RT and low frequency, high losses at $150{ }^{\circ} \mathrm{C}$, and also the highest permittivity among all the samples.

During the sintering of sample $\mathrm{S}$, the pressure is applied onto cold powder. The samples that are first pressed and then heated have a higher flexural strength
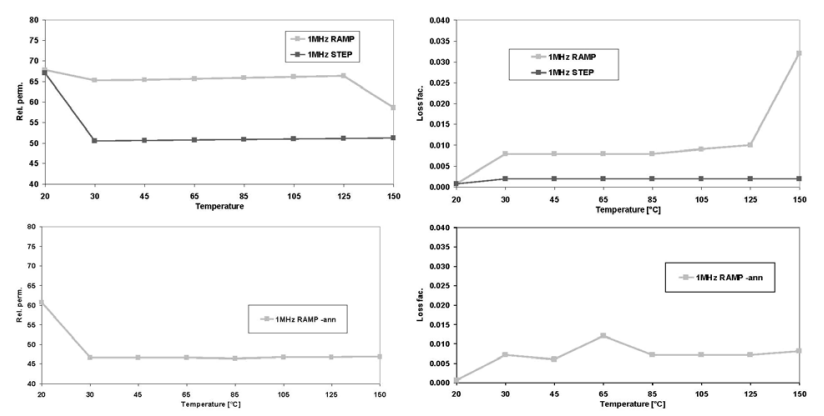

Figure 8: Dielectric patrameters at elevated temperatures of up to $150{ }^{\circ} \mathrm{C}$ : a) permittivity - as-sintered samples, b) loss factor as-sintered samples, c) permittivity - annealed sample R, d) loss factor - annealed sample R

(at yield or break) than the samples that are first heated and then pressed. ${ }^{19}$ The reason for this is a low amount of the finest porosity of the sample that is compressed first. In this case, powder particles are compressed and the powder stacking is better than in the case when the die is manually filled and directly heated. Direct heating leads to the formation of necks between powder particles (the beginning of sintering) while the pressure applied after this step is not able to eliminate the porosity as efficiently as in the above case. When larger pre-loads are applied at lower temperatures (similarly to the "step" process reported here), a high stress working in the small area of a powder contact enhances the formation of strong inter-particle bonds, resulting in the formation of large closed pores. ${ }^{20}$ The time of the application of the temperature high enough for diffusion is also one of the very critical factors of SPS. Based on this set of samples, we can say that sample $\mathrm{S}$ needed more thermal power for perfect sintering.

\subsection{Mechanical properties}

The microhardness of sample $\mathrm{R}$ was $15.3 \pm 2.2 \mathrm{GPa}$ before and $11.5 \pm 2.5 \mathrm{GPa}$ after the annealing. The value of the as-sintered sample $S$ was $16.0 \pm 2.5 \mathrm{GPa}$. The annealing caused crystallite coarsening, similar to the results demonstrated on non-sintered powders and, therefore, the microhardness dropped. Grain (i.e., crystallite) boundaries, more frequent in the as-sintered samples, are advantageous for reaching high hardness. A microhardness of about $16 \mathrm{GPa}$ was observed ${ }^{21}$ on a thin film with a grain size of about $25 \mathrm{~nm}$ and its rapid decrease with the increasing grain size was established in the same paper. A decrease in the grain-boundary quantity brings down the value of the force necessary to deform the material and penetrate it. Also, the hydrated phase, detected with XRD in the annealed sample R, contributed to its decreased microhadness. This phase, however, did not influence the resistivity becasuse the mobility of water molecules bonded into the tantaloxygen lattice is much lower than, for example, the mobility of "free" water coming from ambient moisture ${ }^{22}$. 


\section{CONCLUSIONS}

Using $99 \%$ pure $\mathrm{Ta}_{2} \mathrm{O}_{5}$ powder enabled a sparkplasma-sintering (SPS) compaction with a promising dielectric character even without a subsequent thermal treatment. Dielectric tests in the AC electric field revealed a combination of a high and stable relative permittivity with a low loss factor of the tantalum oxide samples sintered with SPS. The SPS temperature of $1200{ }^{\circ} \mathrm{C}$, i.e., $64 \%$ of the melting point, was proven as high enough to fire the material suitably for use as a dielectric. Two regimes of the SPS pressure-application schedule - "ramp" and step - were tested and, finally, the "step" regime was proven as slightly more suitable because of the lower loss factor and higher DC electric resistivity of the samples in the as-sintered form. However, the use of the process called "ramp", followed by annealing is more suitable for real applications since this two-step procedure delivers to the material, enough thermal energy, promoting the diffusion and, in this way, the sintering. Such a material has an even higher electric resistivity. The $\mathrm{Ta}_{2} \mathrm{O}_{5}$ ceramic is sensitive to the reducing conditions during heating and also to the moisture. Annealing in dry, synthetic, compressed air, instead of the ambient atmosphere, can probably provide for even better dielectric properties.

\section{Acknowledgment}

The authors thank F. Lukac, IPP ASCR, for the XRD measurement and valuable help with its interpretation. P. Veselý, FEE CTU, is acknowledged for the help with SEM observations. The dielectric measurements were sponsored by the Grant Agency of the Czech Technical University in Prague, No. SGS18/070/OHK3/1T/13.

\section{REFERENCES}

${ }^{1}$ L. Ji, Y. Jiang, Laser sintering of transparent Ta2O5 dielectric ceramics, Materials Letters, 60 (2006), 1502-1504, doi:10.1016/ j.matlet.2005.11.060

${ }^{2}$ I. Abuetwirat, Dielectric properties of thin tantalum and niobium oxide layer, Doctoral thesis, Brno University of Technology, Faculty of Electrical Engineering and Communication, Technical University of Brno, Czech Republic (2014)

${ }^{3}$ B. Rahmati, E. Zalnezhad, A. A. D. Sarhan, Z. Kamiab, B. Nasiri Tabrizi, W. A. B. W. Abas, Enhancing the adhesion strength of tantalum oxide ceramic thin film coating on biomedical Ti-6Al-4V alloy by thermal surface treatment, Ceramics International, 41 (2015), 13055-13063, doi:10.1016/j.ceramint.2015.07.090

${ }^{4}$ Y.-Y. Chang, H.-L. Huang, H.-J. Chen, Ch.-H. Lai, C.-Y. Wen, Antibacterial properties and cytocompatibility of tantalum oxide coatings, Surface \& Coatings Technology, 259 (2014), 193-198, doi:10.1016/j.surfcoat.2014.03.061 0257-8972

${ }^{5}$ J. Li, W. Dai, G. Wu, N. Guan, L. Li, Fabrication of Ta2O5 films on tantalum substrate for efficient photocatalysis, Catalysis Communications, 65 (2015), 24-29, doi:10.1016/j.catcom.2015. 02.006

${ }^{6}$ A. C. Cefalas, Z. Kollia, N. Spyropoulos-Antonakakis, V. Gavriil, D. Christofilos, G. Kourouklis, V. V. Semashko, V. Pavlov, E.
Sarantopoulou, Surface profile gradient in amorphous $\mathrm{Ta}_{2} \mathrm{O}_{5}$ semi conductive layers regulates nanoscale electric current stability, Applied Surface Science, 396 (2017), 1000-1019, doi:10.1016/ j.apsusc.2016.11.076

${ }^{7}$ J. Lee, W. Lu, E. Kioupakis, Electronic properties of tantalum pentoxide polymorphs from first-principles calculations, Applied Physics Letters, 105 (2014), 202108, doi:10.1063/1.4901939

${ }^{8}$ G. S. Oehrlein, Oxidation temperature dependence of the $\mathrm{dc}$ electrical conduction characteristics and dielectric strength of thin $\mathrm{Ta}_{2} \mathrm{O}_{5}$ films on silicon, Journal of Applied Physics, 59 (1986) 5, 1587-1595, doi:10.1063/1.336468

${ }^{9}$ S.-H. Huang, P.-H. Cheng, Y.-Y. Chen, Effects of $\mathrm{O}_{2} / \mathrm{Ar}$ ratio and annealing temperature on electrical properties of $\mathrm{Ta}_{2} \mathrm{O}_{5}$ ?1m prepared by magnetron sputtering, Chinese Physics B, 22 (2013) 2, 027701, doi:10.1088/1674-1056/22/2/027701

${ }^{10}$ H. Yoshida, K. Morita, B.-N. Kim, K. Soga, Low temperature spark plasma sintering of tin oxide doped with tantalum oxide, Journal of the Ceramic Society of Japan, 124 (2016) 9, 932-937, doi:10.2109/jcersj2.16133

${ }^{11}$ E. Olevsky, E. Khaleghi, C. Garcia, W. Bradbury, Fundamentals of Spark-Plasma Sintering: Applications to Net-Shaping of High Strength Temperature Resistant Components, Materials Science Forum, 654 (2010), 412-415, doi:10.4028/www.scientific.net/ MSF.654-656.412

${ }^{12}$ P. Ctibor, J. Č́ižek, J. Sedláček, F. Lukáč, Dielectric properties and vacancy-like defects in plasma-sprayed barium titanite, Journal of the American Ceramic Society, 100 (2017) 7, 2972-2983, doi: $10.1111 /$ jace. 14840

${ }^{13}$ R. Hollerweger, D. Holec, J. Paulitsch, P. H. Mayrhofer, Magnetic field strength influence on the reactive magnetron sputter deposition of Ta2O5, Journal of Physics D: Applied Physics, 46 (2012) 33, 335203, doi:10.1088/0022-3727/46/33/335203

${ }^{14}$ H. Monreal, G. Mata, R. Pacheco, G. Bueno, J. Ruacho, J. Chacon, Synthesis and Characterization of $\mathrm{Ta}_{2} \mathrm{O}_{5}$ Nnanoparticles by Sol-Gel Technique in a Polysacharide Matrix, Digest Journal of Nanomaterials and Biostructures, 11 (2016) 3, 991-996

${ }^{15}$ P.-H. Chang, H.-Y. Liu, Structures of tantalum pentoxide thin films formed by reactive sputtering of Ta metal, Thin Solid Films, 258 (1995), 56-63, doi:10.1016/0040-6090(94)06402-4

${ }^{16}$ A. Agulyanski, Fluorine chemistry in the processing of tantalum and niobium, in: Anatoly Agulyanski (Ed.), Chemistry of Tantalum and Niobium Fluoride Compounds (1st ed.), 2004

${ }^{17} \mathrm{~S}$. Thomas, Silicate and aluminate based dielectric ceramics for microwave communication, Doctoral Thesis, National institute for interdisciplinary science and technology (CSIR), Thiruvananthapuram, India 2010

${ }^{18}$ I. Abuetwirat, K. Liedermann, Dielectric properties of thin tantalum oxide layers at solid tantalum capacitors, Proc. of the International Conference on Computer Information Systems and Industrial Applications (CISIA) 2015

${ }^{19}$ J. Cinert, Study of machanisms of the spark plasma sintering technique, Doctoral Thesis, Czech Technical University in Prague, Faculty of Electrical Engineering, Czech Republic 2018

${ }^{20}$ K. Morita, B.-N. Kim, H. Yoshida, H. Zhang, K. Hiraga, Y. Sakka, Effect of loading schedule on densi?cation of $\mathrm{MgAl}_{2} \mathrm{O}_{4}$ spinel during spark plasma sintering (SPS) processing, Journal of the European Ceramic Society, 32 (2012), 2303-2309, doi:10.1016/j.jeurceramsoc. 2012.02.016

${ }^{21}$ D. Bernoulli, U. Müller, M. Schwarzenberger, R. Hauert, R. Spolenak, Magnetron sputter deposited tantalum and tantalum nitride thin films: An analysis of phase, hardness and composition, Thin Solid Films, 548 (2013), 157-161, doi:10.1016/j.tsf.2013.09.055

${ }^{22} \mathrm{~K}$. Truhlar, Impact of climatic factors on dielectric spectra of ceramic materials, Bachelor's Thesis, Brno University of Technology, Brno 2008 